\title{
PENGARUH PELABUHAN SEBAGAI SIMPUL PERTUMBUHAN TERHADAP PENGEMBANGAN WILAYAH Studi Kasus : Pelabuhan Paelangkuta Nusantara Raha
}

\author{
Sitti Astija ${ }^{1}$, Ardiana Yuli Puspitasari ${ }^{2}$ \\ Program Studi Perencanaan Wilayah dan Kota Universitas Islam Sultan Agung Semarang ${ }^{1), 2)}$
}

\begin{abstract}
Muna is an archipelago in Southeast Sulawesi, so as to distribute the crops and the potential of the region in Muna are more optimal by using of sea transportation. The port is expected to support the activities of loading and unloading of goods, up and down the passenger activities, so that the ship visits activity took place smoothly. On the other hand the port has a function of interface, meaning that it provides a variety of facilities and services which is required for transferring from ship to the land transportation and move goods from one ship to others. Node port terminal growth Paelangkuta Raha archipelago is a port-type collector. The port terminal is used as transportation among regions within the province or interprovincial. As well as being a place of transporting goods distribution services in the area of Muna Regency universal. The purpose of this study was to know the Influence of growth Node of Port Paelangkuta Raha toward Muna Regional development. To achieve these objectives, quantitative research in rationalistic approach is used in this research by using a simple linear regression analysis using SPSS16 application. Regional development made possible by the central growth which is based on the development of human resources and natural resources, both types of resource development takes place so that raises the flow of goods. Raw material is transported from producing areas to the plant site and the goods results are transported from producer to consumer. The findings from this research is that the growth Node of Port Paelangkuta Raha Muna affect the development area.
\end{abstract}

Keywords: Node, Growth

\section{ABSTRAK}

Kabupaten Muna merupakan daerah kepulauan di Sulawesi Tenggara, sehingga untuk menyalurkan atau mendistribusikan hasil bumi dan potensi wilayah di Kabupaten Muna lebih optimal menggunakan transportasi laut. Pelabuhan diharapkan dapat menunjang aktifitas bongkar muat barang, aktifitas naik turun penumpang dan aktifitas kunjungan kapal sehingga berlangsung dengan lancar. Disisi lain pelabuhan mempunyai fungsi interface dalam arti pelabuhan menyediakan berbagai fasilitas dan pelayanan jasa yang dibutuhkan untuk perpindahan dari kapal keangkutan darat atau sebaliknya dan memindahkan barang-barang dari kapal yang satu ke kapal yang lainnya. Simpul pertumbuhan terminal pelabuhan Paelangkuta Nusantara Raha merupakan pelabuhan tipe pengumpul. Terminal pelabuhan ini digunakan sebagai jalur transportasi antar wilayah dalam propinsi maupun antar propinsi. Serta menjadi tempat jasa distribusi pengangkutan barang di wilayah Kabupaten Muna yang bersifat universal. Tujuan dari penelitian ini adalah mengetahui Pengaruh Simpul Pertumbuhan Paelangkuta Nusantara Raha terhadap pengembangan Wilayah Kabupaten Muna. Untuk mencapai tujuan tersebut, maka digunakan jenis metode penelitian kuantitatif pendekatan rasionalistik dengan menggunakan alat analisis regresi linear sederhana menggunakan aplikasi SPSS16. Pengembangan wilayah dimungkinkan oleh adanya pertumbuhan sentral, yang bertumpu pada pengembangan sumberdaya manusia dan sumberdaya alamnya, pengembangan kedua jenis sumberdaya tersebut berlangsung sedemikian sehingga menimbulkan arus barang. Bahan mentah diangkut dari daerah penghasil ke lokasi pabrik dan barang hasilnya diangkut dari produsen ke konsumen. Temuan studi yang diperoleh dari penelitian ini yaitu bahwa Simpul Pertumbuhan Pelabuhan Paelangkuta Nusantara Raha mempengaruhi Wilayah Kabupaten Muna.

Kata Kunci: Simpul Pertumbuhan, Pengembangan Wilayah 


\section{PENDAHULUAN}

Simpul pertumbuhan yaitu lokasi atau wilayah yang memiliki kemudahan askes dalam kedudukan sentral serta merangsang tumbuhnya dinamika masyarakat dalam mewujudkan daya pengembangan wilayah yang bersifat universal (Rahardjo Adisasmita, 2008). Ada dua faktor penting yang harus diperhatikan dalam pemahaman peranan simpul-simpul, yaitu mengenai fungsi-fungsi simpul dan hirarki simpul dalam sistem spasial. Peranan hirarki simpul terhadap suatu daerah dimaksudkan bahwa aktivitas arus barang dan penumpang pada masing-masing daerah, serta kegiatan jasa pendistribusian (barang) yang mencerminkan suatu darah dapat membentuk hirarki daerah. Susunan simpul utama dengan simpul-simpul yang berdekatan terbentuk dari adanya hubungan fugsional antar simpul atau sebagai pusat kegiatan daerah (Mappangara, dkk, 2012).

Pada studi ini, simpul pertumbuhan yang dimaksud yaitu simpul pertumbuhan Pelabuhan. Menurut Peraturan Pemerintah (PP) Nomor 11 tahun 1983 pelabuhan atau dermaga adalah tempat berlabuh atau bertambatnya kapal laut atau sungai dan kendaraan air lainnya untuk menaikan dan menurunkan penumpang, bongkar muat barang dan hewan serta merupakan daerah lingkungan kerja kegiatan ekonomi. Indonesia merupakan negara kepulauan terbesar di dunia, yang mana membutuhkan pelabuhan sebagai salah satu sektor yang bergerak di bidang pelayaran dan tempat pengangkutan barang sehingga perlu untuk dikelola dengan baik dan efisien agar tetap terjaga dan berfungsi secara optimal. (Setiono, 2010). Kinerja sektor pelabuhan dibutuhkan dalam mendukung kemampuan saing produsen baik pada pasar nasional dan internasional, mendistribusikan kedalam dengan efisien dan lebih general, selain itu juga mendukung keterpaduan dan integritas ekonomi nasional. Hal tersebut bisa menjadi kunci dalam meningkatkan simpul pertumbuhan pelabuhan suatu wilayah, yaitu dengan tetap mempertahankan aspek peningkatan kinerja pada sektor pelabuhan. Pelabuhan ju*ga menjadi pintu gerbang perekonomian suatu daerah, terdapatnya pelabuhan pada suatu daerah menjadi salah satu daya dukung dalam perkembangan wilayah. Sebelum itu harus ditentukan tiap-tiap sektor yang menjadi potensi untuk dikembangkan, sehingga apabila terjadi peningkatan permintaan barang dan jasa pada wilayah tersebut, harus sudah ada kesiapsiagaan baik dari sistem sarana dan prasarana terutama jaringan transportasi yang dapat menduking kegiatan pendistribusian barang ke luar daerah (Gantara dan Achmadi, 2012). 
Berdasarkan Peraturan Pemerintah Nomor 26 Tahun 2008 Tentang Rencana Tata Ruang Wilayah Nasional, Raha tepatnya Kecamatan Katobu ditetapkan sebagai salah satu PKW (Pusat Kegiatan Wilayah) di Provinsi Sulawesi Tenggara. Rencana pengembangan/peningkatan fungsi perkotaan Raha diarahkan untuk menunjang percepatan pengembangan kota-kota pusat pertumbuhan nasional. Kondisi saat ini, Raha merupakan ibukota pemerintahan kabupaten yang telah didukung dengan adanya pelabuhan nasional/pengumpul dan jalan nasional serta jalan provinsi. Pelabuhan nasional/pengumpul di Wilayah Kabupaten Muna yaitu Pelabuhan Paelangkuta Nusantara Rahaterletak di Ibu Kota Kabupaten, tepatnya di Kelurahan Raha I, Kecamatan Katobu.

Permasalahan yang ada dilokasi adalah Cakupan pertumbuhan ekonomi yang kurang menyeluruh dalam pendistribusian barang dan jasa di wilayah Kabupaten Muna. Serta akses dan pelayanan infrastruktur transportasi laut kurang optimal.

\section{METODOLOGI PENELITIAN}

Metode penelitian yang digunakan dalam studi penelitian ini yaitu metode Deduktif Kuantitatif Positivistik (Purwanto dan Sulistyastuti, 2011). Pada studi ini menggunakan alat analisis Regresi Linear sederhana. Analisis ini untuk mengetahui arah hubungan antara variabel independen $(\mathrm{X})$ dengan variabel dependen $(\mathrm{Y})$. Apakah variabel independen (X) berhubungan positif atau negatif dan untuk memprediksi nilai dari variabel dependen (Y) apabila nilai variabel independen mengalami kenaikan atau penurunan. Dengan persamaan:

\section{Rumus:}

$\mathbf{Y}=\mathbf{a}+\mathbf{b X}$

Keterangan:

$\mathrm{X}$ : Simpul Pertumbuhan Pelabuhan

Y : Pengembangan wilayah Kabupaten Muna

a : Konstanta (nilai $\mathrm{Y}$ apabila $\mathrm{X}=0$ )

$\mathrm{b}$ : Koefisien regresi (nilai peningkatan ataupun penurunan).

\section{HIPOTESIS}

Hipotesis dinyatakan dengan ketentuan:

$\mathrm{H}_{0}: \beta=0$, berarti "Simpul pertumbuhan Pelabuhan Paelangkuta Nusantara Raha tidak mempengaruhi pengembangan wilayah Kabupaten Muna". 
$\mathrm{H}_{\mathrm{a}}: \beta \neq 0$, berarti "Simpul pertumbuhan Pelabuhan Paelangkuta Nusantara Raha mempengaruhi pengembangan wilayah Kabupaten Muna”.

Pelabuhan merupakan wilayah perairan yang terlindungi terhadap gelombang laut, fasilitas yang mendukung pengoperasian pelabuhan secara optimal yaitu dermaga yang merupakan tempat dimana kapal dapat melakukan bongkar muat barang, kran-kran untuk bongkar muat-barang, transito atau biasa disebut gudang laut dan tempat-tempat penyimpanan hasil bongkar muat barang, serta gudang-gudang tempat menyimpan barang dalam waktu yang lebih lama dengan menunggu pengiriman ke daerah yang dituju atau biasa disebut pengapalan (Kastanya, 2013). Pelabuhan dibedakan menjadi beberapa macam dilihat dari segi tinjauannya menjadi, segi penyelenggaraannya, pengusahaannya, fungsi dalam perdagangan nasional dan internasional, segi kegunaan dan letak geografinya (Kastanya, 2013).

Pembangunan mempunyai makna yaitu merupakan "proses" pembangunan didasarkan pada proses penggambaran suatu perkembangan, baik berupa proses pertumbuhan (growth) ataupun perubahan (change) dalam kehidupan bermasyarakat dalam kehidupan bersosial dan berbudaya. Kondisi tersebut adalah merupakan kondisi dari kehidupan masyarakat luas (society). Memperhatikan pembangunan pada masyarakat adalah hal yang baru dalam paradigma pembangunan sekarang (Henryk, 2013).

Patton dalam (Henryk, 2013), mendifinisikan pembangunan menjadi beberapa pengertian meliputi:

1. Pembangunan adalah suatu proses yang dimaksudkan bahwa setiap usaha yang dihasilkan dari pembanguanan tentunya membutuhkan keterkaitan antar pelaksanaan perencanaannya secara eksternal berdasarkan atas skala prioritas dan langkah-langkah tertentu.

2. Pembangunan berdasarkan usaha-usaha yang harus dilaksanakan secara sadar yang berarti bahwa setiap usaha yang dilakukan dalam pembangunan harus berlandaskan pada motivasi dasar, sasaran dan tujuan yang jelas dan rasional, dengan kata lain tidak dilandaskan pada pemikiran-pemikiran emosional saja. Sebaiknya, pembangunan dilaksanakan dengan teratur, yang berarti harus terencana dan berorientasi pada tolak ukur pertumbuhan dan perubahan suatu wilayah.

3. Pembangunan dapat dilakukan dalam perencanaan maupun dalam pelaksanaannya bagaimanapu juga harus mengarah ke masa sekarang, artinya harus diperuntukkan untuk menumbuhkan suatau inovasi terbaru dengan memberikan hasil bentuk cara hidup yang 
lebih baik dari sebelumnya termasuk prospek pembangunan di masa mendatang yang dapat dilihat dari pengembangan potensi dan sumber kehidupan dalam masyarakat luas.

4. Multi-dimensional dapat dicirikan dari sifat dan juga pikiran modernisasi yang akan dicapai, yang memiliki arti bahwa mencakup keseluruha aspek kehidupan. Hal tersebut di dorong dengan adanya kesadaran bahwa usaha didapatkan dari pembinaan bangsa dan negara serta masyarakat umumnya sesuai dengan yang direncanakan.

Meurut Zamhariri (2008:23) dalam Henryk (2013) tujuan dalam pembangunan dapa dirumuskan menajadi beberapa hal sebagai berikut:

1. Dapat menciptakan keadaan secara umum yang mendorong pembangunan

2. Dapat memanfaatkan potensi dari sumber daya yang ada sehingga dapat memberikan manfaat pembangunan oleh pemerintah yang terkait, dunia usaha, serta masyarat umumnya.

3. Dapat melaksanakan beberapa pemantauan dalam berbagai sektor.

4. Dapat melaksanakan langkah-langkah dalam melakukan tindakan dan dorongan bagi kegiatan serta investasi swasta.

Berbagai macam penelitian tentang transportasi dan pembangunan dapat dianalisis melalui "gap" pada dua faktor utama, yaitu (1) penciptaan peluang ekonomi, dan (2) respons terhadap peluang ekonomi. Faktor pertama penciptaan peluang ekonomi ini terlihat pada kuantitas dan kualitas sumberdaya didaerah, perubahan aktual tarif angkutan dan pelayanan, serta tingkat harga komoditas. Faktor kedua respons terhadap peluang ekonomi tergantung pada kemampuan dalam menangkap peluang dan sikap atau tingkah laku terhadap pergeseran ekonomi.

Pentingnya peranan pelabuhan laut dalam pembangunan telah banyak diutarakan oleh parah ahli, diantaranya dikemukakan sebagai berikut:

1. Post as modern transport node

2. Post as a spatial system in the development proces

3. Gatewayport concept

4. Port as servant of shipping

5. Pots as multipler 


\section{Proses Pertumbuhan Wilayah}

\section{Pertumbuhan Dari Dalam}

Pembahasan mengenai pertumbuhan wilayah dari dalam di maksudkan sebagai telaahan atau wacana yang mengamati proses berlangsungnya pertumbuhan pembangunan dalam suatu wilayah yang ditinjau dari segi strukturak (keterkaitan antar sektor) maupun dari segi hubungan fungsional (interaksi antar subsistem dalam suatu wilayah).

\section{Pertumbuhan dari luar}

Pembahasan pertumbuhan wilayah dari luar lebih menekannya perhatian pada keterkaitan suatu wilayah dengan wilayah lain diluarnya. Faktor utama unruk pembangunan dan pertumbuhan ekonomi wilayah adalah investsi (akumulasi modal), inovasi (kemjuan teknologi), dan sumber daya alam.

\section{Teori tempat sentral}

Teori tempat sentral untuk sebagian bersifat positif karena berusaha menjelaskan pola aktual arus pelayanan jasa, dan untuk sebagian lagi bersifat normatif karena berusaha menentukan pola optimal distribusi tempat-tempat sentral. Keduanya mempunyai kontribusi pada pemahaman interrelasi spasial dan mengenai kota-kota sebagai sistem di dalam sistem perkotaan.

\section{Teori simpul jasa distribusi menggunakan pendekatan arus barang}

Keseimbangan antar daerah, dalam hal tingkat pertumbuhannya pada prinsipnya dicapai juga dengan jalan membuat seimbang SWP-SWP yang terbentuk dan tersebar pada wilayah nasional. Dalam rangka melengkapi Konsep Pengembangan Wilayah Nasional dengan variabel. Kriteria serta dimensi yang lebih nyata, perlu dimiliki pengetahuan tentang apa yang dinamakan Struktur Pengembangan Wilyah Tingkat Nasional, yakni yang memberikan gambaran mengenai.

1) Penyebaran SWP-SWP pada wilayah nasional.

2) Orientasi dan tingkat perkembangan masing-masing SWP, dan

3) Hubungan ketergantungan antara SWP. 


\section{HASIL DAN PEMBAHASAN}

\section{A. Uji Validitas}

Tabel 1. Uji Validitas

\begin{tabular}{|l|c|c|c|}
\hline \multirow{2}{*}{ Variabel } & $\begin{array}{c}\text { No.Item } \\
\text { Kuesioner } \\
\text { berdasrkan } \\
\text { variable }\end{array}$ & $\begin{array}{c}\text { Signifikan } \\
\text { si }\end{array}$ & Keterangan \\
\hline $\begin{array}{l}\text { Simpul } \\
\text { Pertumbuhan }\end{array}$ & 1 & 0,000 & VALID \\
\cline { 2 - 4 } $\begin{array}{l}\text { Pelabuhan } \\
\text { Pealangkuta } \\
\text { Nusantara Raha }\end{array}$ & 2 & 0,000 & VALID \\
\cline { 2 - 4 } & 3 & 0,000 & VALID \\
\cline { 2 - 4 } $\begin{array}{l}\text { Pengembangan } \\
\text { Wilayah }\end{array}$ & 4 & 0,000 & VALID \\
\cline { 2 - 4 } $\begin{array}{l}\text { Kabupaten } \\
\text { Muna }\end{array}$ & 5 & 0,000 & VALID \\
\cline { 2 - 4 } & 2 & 0,000 & VALID \\
\cline { 2 - 4 } & 3 & 0,000 & VALID \\
\cline { 2 - 4 } & 5 & 0,000 & VALID \\
\hline
\end{tabular}

Sumber: Hasil Analisis Penyusun menggunakan SPSS16, 2014

\section{B. Uji Reliabilitas}

Pada uji reliabilitas tiap variabel mewakili keseluruhan indikator kuesioner pada tiap variabel, yang dapat dilihat pada tabel berikut:

Tabel 2. Uji Reliabilitas

\begin{tabular}{|c|l|c|c|}
\hline No & \multicolumn{1}{|c|}{ Variabel } & Alpha & Keterangan \\
\hline 1 & $\begin{array}{l}\text { Simpul Pertumbuhan } \\
\text { Pelabuhan Paelangkuta } \\
\text { Nusantara Raha }\end{array}$ & 0,606 & RELIABEL \\
\hline 2 & $\begin{array}{l}\text { Pengembangan } \\
\text { Wilayah KAbupaten } \\
\text { Muna }\end{array}$ & 0,607 & RELIABEL \\
\hline
\end{tabular}

Sumber: Hasil Analisis Penyusun menggunakan SPSS16, 2014

\section{Analisis Regresi Linear Sederhana}

Tabel 3. Hasil Regresi Linear Sederhana Coefficients ${ }^{\mathrm{a}}$

\begin{tabular}{|c|c|c|c|c|c|}
\hline \multirow[b]{2}{*}{ Model } & \multicolumn{2}{|c|}{$\begin{array}{l}\text { Unstandardized } \\
\text { Coefficients }\end{array}$} & \multirow{2}{*}{$\begin{array}{c}\begin{array}{c}\text { Standardized } \\
\text { Coefficients }\end{array} \\
\text { Beta }\end{array}$} & \multirow[b]{2}{*}{$\mathrm{t}$} & \multirow[b]{2}{*}{ Sig. } \\
\hline & B & Std. Error & & & \\
\hline $\begin{array}{l}\text { 1(Constant) } \\
\text { Total Simpul } \\
\text { Pertumbuhan } \\
\text { Pelabuhan } \\
\text { Paelangkuta } \\
\text { Nusantara Raha }\end{array}$ & 10.612 & 2.245 & .262 & 4.727 & .000 \\
\hline
\end{tabular}

a. Dependent Variable: Total Pengembangan Wilayah Kabupaten Muna

Sumber: Hasil Analisis Penyusun menggunakan SPSS16, 2014 
Model persamaan yang dapat dituliskan dari hasil regresi tersebut adalah sebagai berikut:

\section{$\mathrm{Y}=\mathbf{0 . 2 6 2} \mathrm{X}$}

Hasil persamaan regresi linear sederhana tersebut memberikan pengertian bahwa nilai koefisien $\mathrm{X}$ bernilai positif sebesar 0.262 dengan tingkat signifikan 0.010 mempunyai arti bahwa Simpul Pertumbuhan Pelabuhan Paelangkuta Nusantara Raha dapat mempengaruhi Pengembangan Wilayah Kabupaten Muna.

\section{Koefisien Determinasi}

Tabel 4. Hasil Uji Koefisien Determinasi

\begin{tabular}{|l|c|c|c|r|}
\hline $\begin{array}{l}\text { Mode } \\
\mathrm{l}\end{array}$ & $\mathrm{R}$ & $\begin{array}{c}\mathrm{R} \\
\text { Squar } \\
\mathrm{e}\end{array}$ & $\begin{array}{c}\text { Adjusted R } \\
\text { Square }\end{array}$ & $\begin{array}{c}\text { Std. Error } \\
\text { of the } \\
\text { Estimate }\end{array}$ \\
\hline 1 & $.262^{\mathrm{a}}$ & .069 & .059 & 1.940 \\
\hline
\end{tabular}

a. Predictors: (Constant), T SP

b. Dependent variabel pengembangan wilayah Kabupaten Muna

Sumber: Hasil Analisisi Penyusun menggunakan SPSS16, 2014

Dari tabel diatas menjelaskan bahwa besarnya nilai koefisien determinasi ditunjukan oleh nilai Adjusted R Square yaitu sebesar 0.059. Dimana menunjukan bahwa simpul pertumbuhan pelabuhan paelangkuta nusantara raha mempengaruhi pengembangan wilayah kabupaten muna sebesar 5,9\% sedangkan sisanya dijelaskan oleh faktor lain yang tidak diamati oleh peneliti.

\section{E. Pengujian Hipotesis}

\section{Uji t}

Uji hipotesis pada penelitian ini menggunakan uji t. uji t digunakan untuk menguji signifikan secara parsial yaitu variabel independen (X) dan dependen (Y). Masing-masing uji hipotesis ini menggunakan taraf signifikan sebesar Alpha $=5 \%$. 
Tabel 5. Uji Nilai t

\begin{tabular}{|l|r|r|r|r|r|}
\hline & \multicolumn{2}{|c|}{ Unstandardized Coefficients } & $\begin{array}{c}\text { Standardized } \\
\text { Coefficients }\end{array}$ & & \\
\cline { 2 - 6 } Model & $\mathrm{B}$ & Std. Error & Beta & $\mathrm{t}$ & Sig. \\
\hline $1 \quad$ (Constant) \\
$\begin{array}{l}\text { Total Simpul } \\
\text { Pertumbuhan } \\
\text { Pelabuhan } \\
\text { Paelangkuta } \\
\text { Nusantara Raha }\end{array}$ & 10.612 & 2.245 & & 4.727 & .000 \\
\hline
\end{tabular}

a. Dependent Variable: Total Pengembangan Wilayah Kabupaten Muna Sumber: Hasil Analisisi Penyusun menggunakan SPSS16, 2014

Berdasarkan dari hasil uji $\mathrm{t}$ dengan variabel dependen pengembangan wilayah Kabupaten Muna dengan menggunakan taraf nyata (Alpha) $=5 \%$ jumlah sampel $(n)=95$, jumlah variabel $(\mathrm{k})=1$, derajat bebas $(\mathrm{df})=\mathrm{n}-\mathrm{k}=95-1$. Dengan uji dua arah, maka diketahui nilai $t$ tabel adalah $+2,000$ dan $-2,000$.

Pengaruh Simul Pertumbuhan Pelabuhan Paelangkuta Nusantara Raha terhadap Pengembangan Wilayah Kabupaten Muna ditunjukan dengan nilai standar koefisien sebesar 0,262 dengan signifikansi 0,010 lebih kecil dari taraf nyata 0,05 ( $\operatorname{sig}>\alpha$ ) yang berarti signifikan. Adapun jika dilihat nilai t hitung sebesar 2,617 maka berada pada area tolak $\mathrm{H}_{0}$ $(2,617>2,000)$ sehingga Simpul Pertumbuhan Pertumbuhan Paelangkuta Nusantara Raha dapat mempengaruhi Pengembangan Wilayah.

\section{Uji F}

Tabel 6. Uji Nilai F

\begin{tabular}{|l|r|r|r|c|c|}
\hline Model & $\begin{array}{c}\text { Sum of } \\
\text { Squares }\end{array}$ & Df & $\begin{array}{c}\text { Mean } \\
\text { Square }\end{array}$ & F & Sig. \\
\hline 1 Regression & 25.755 & 1 & 25.755 & 6.846 & $.010^{\mathrm{a}}$ \\
Residual & 349.866 & 93 & 3.762 & & \\
Total & 375.621 & 94 & & & \\
\hline
\end{tabular}

a. Predictors: (Constant), Total Simpul Pertumbuhan Pelabuhan

Paelangkuta Nusantara Raha

b. Dependent Variable: Total Pengembangan Wilayah KAbupaten Muna

Sumber: Hasil Analisisi Penyusun menggunakan SPSS16, 2014

Berdasarkan nilai statistik menunjukan hasil nilai $\mathrm{F}$ hitung $=6.846$. Dengan menggunakan batas signifikan 0,05 maka diperoleh nilai signifikansi tersebut 0.010. hal ini 
berarti model regresi dapat digunakan untuk membuat estimasi Pengaruh Pengembangan Wilayah.

Tabel 7. Hasil Temuan Studi Pengaruh Simpul Pertumbuhan Pelabuhan Paelangkuta Nusantara Raha terhadap Pengembangan Wilayah Kabupaten Muna

\begin{tabular}{|c|c|c|}
\hline No & Analisis & Hasil Temuan Studi \\
\hline 1. & $\begin{array}{l}\text { Uji Validitas Reliabilitas } \\
\text { dan Validitas }\end{array}$ & $\begin{array}{l}\text { Uji validitas dilihat dari tingkat signifikan dari tiap } \\
\text { kuesioner. Apabila tingkat signifikannya } 0 \text { maka } \\
\text { kuesioner tersebut dikatakan valid. } \\
\text { Uji reliabilitas dari kedua variabel, dengan } \\
\text { croncbanch alpha }>0,6 \text { (dalam Imam Ghozali, 2005) } \\
\text { untuk variabel simpul pertumbuhan pelabuhan } \\
\text { paelangkuta Nusantara Raha (X) didapatkan nilai } \\
\text { sebesar 0,606 dan untuk variabel Pengembangan } \\
\text { Wilayah Kabupaten Muna (Y) didapatkan nilai } \\
\text { sebesar } 0,607 \text {. Masing-masing variabel tersebut dika } \\
\text { takan telah masuk dalam kriteria reliabilitas tinggi. } \\
\text { Sehingga kedua variabel tersebut dikatakan telah } \\
\text { memenuhi uji reliabilitas }\end{array}$ \\
\hline 2. & $\begin{array}{l}\text { Pengaruh Simpul } \\
\text { Pertumbuhan Pelabuhan } \\
\text { Paelangkuta Nusantara } \\
\text { Raha terhadap } \\
\text { Pengembangan Wilayah } \\
\text { Kabupaten Muna }\end{array}$ & $\begin{array}{l}\text { Pada uji t yang telah dilakukan menunjukan nilai } \mathrm{t} \\
\text { hitng lebih besar dari t tabel }(2,617>2,000) \text {, maka } \mathrm{H}_{\mathrm{a}} \\
\text { diterima dan } \mathrm{H}_{0} \text { ditolak. Jadi, Simpul Pertumbuhan } \\
\text { Pelabuhan Paelangkuta Nusantara Raha berpengaruh } \\
\text { positif dan signifikan terhadap Pengembangan } \\
\text { Wilayah Kabupaten Muna. } \\
\text { Berdasarkan hasil perhitungan regresi linear } \\
\text { sederhana dapat diketahui bahwa koefisien } \\
\text { determinasi yang diperoleh sebesar } 0,059 \text { atau } 5,9 \% \text {. } \\
\text { Dimana menunjukan bahwa Simpul Pertumbuhan } \\
\text { Pelabuhan Paelangkuta Nusantara Raha hanya dapat } \\
\text { mempengaruhi Pengembangan Wilayah Kabupaten } \\
\text { Muna sebesar } 5,9 \% \text { dan sisanya dipengaruhi oleh } \\
\text { variabel lain yang tidak diteliti dalam penelitian ini. }\end{array}$ \\
\hline
\end{tabular}

Sitti Astija, Ardiana Yuli Puspitasari. I25 Pengaruh Simpul Pertumbuhan Pelabuhan ... 


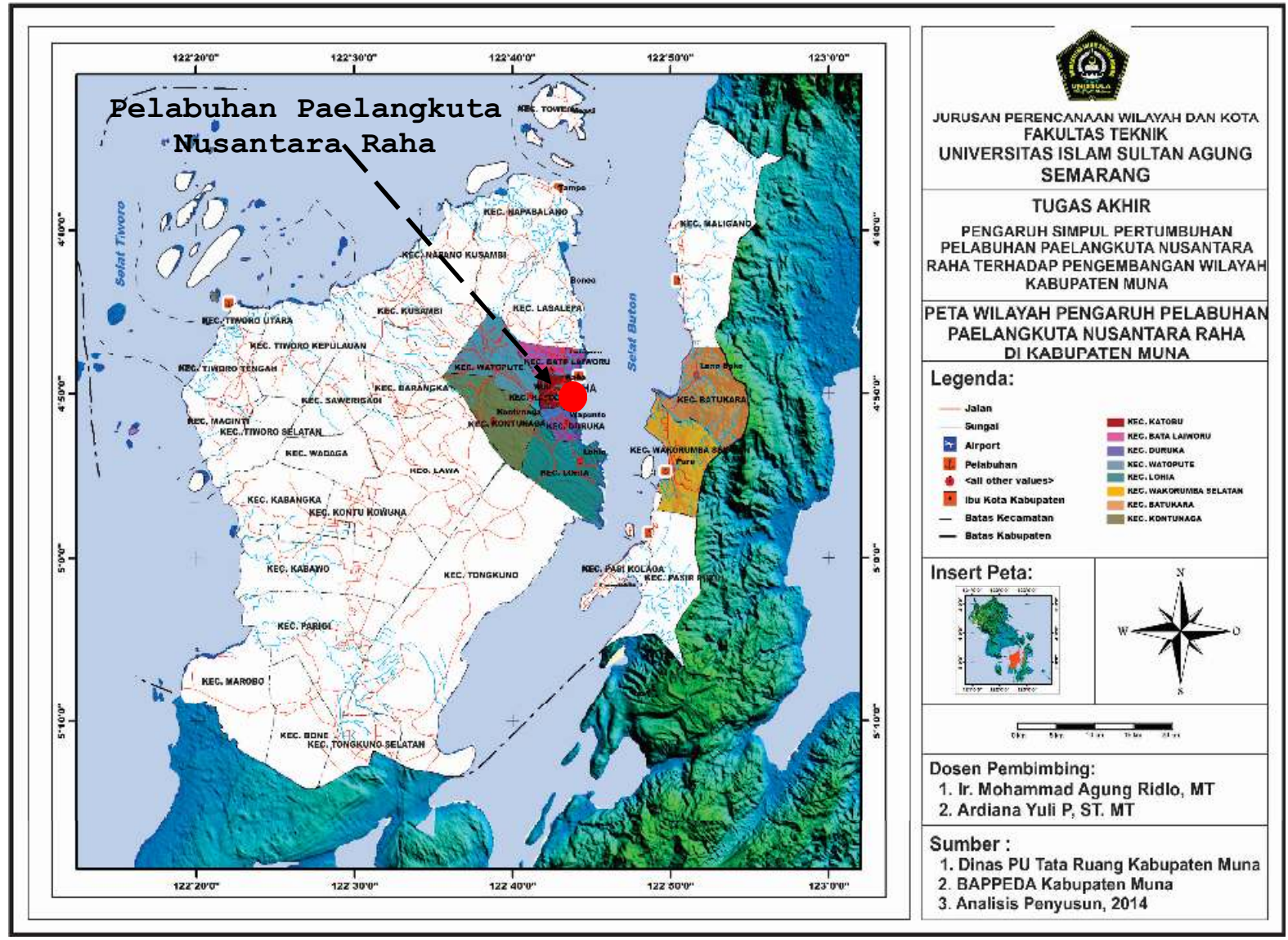

Gambar 1. Peta Wilayah Pengaruh Pelabuhan Paelangkuta Nusantara Raha di Kabupaten Muna

Pengaruh Simpul Pelabuhan Paelangkuta Nusantara Raha terhadap pengembangan Wilayah Kabupaten Muna lebih dominan terlihat pada Wilayah Pengembangan I (Kecamatan Katobu, Kecamatan Duruka, Kecamatan Lohia, Kecamatan Bata Laiworu, Kecamatan Kontunaga, Kecamatan Watopute). Dikarenakan Simpul Pertumbuhan Pelabuhan Paelangkuta Nusantara Raha berada pada Wilayah Pengembangan I, yaitu berada di Kecamatan Katobu, dimana di Kecamatan Katobu ini merupakan pusat pertumbuhan wilayah Kabupaten Muna. Serta pada Wilayah Pengembangan IV (Kecamatan Batukara dan Kecamatan Wakorumba Selatan) mendapatkan pengaruh langsung dalam pendistribusian barang maupun jasa karena lokasi Wilayah Pengembangan IV berhadapan dengan Wilayah Simpul Pertumbuhan Pelabuhan Paelangkuta Nusantara Raha. 


\section{KESIMPULAN DAN SARAN}

\section{A. Kesimpulan}

Keterkaitan pengaruh Simpul Pertumbuhan Pelabuhan Paelangkuta Nusantara Raha terhadap Pengembangan Wilayah Kabupaten Muna dengan pengujian hipotesis menggunakan alat analisis regresi linear sederhan dengan menggunakan software SPSS16 bahwa $\mathrm{H}_{\mathrm{a}}$ dapat diterima. Artinya Simpul Pertumbuhan Pelabuhan Paelangkuta Nusantara Raha mempengaruhi Pengembangan Wilayah Kabupaten Muna. Hal ini pada uji t yang telah dilakukan menunjukan nilai t hitng lebih besar dari t tabel $(2,617>2,000)$.

Dengan koefisien determinasi yang diperoleh sebesar 0,059 atau 5,9\%. Dimana menunjukan bahwa Simpul Pertumbuhan Pelabuhan Paelangkuta Nusantara Raha hanya dapat mempengaruhi Pengembangan Wilayah Kabupaten Muna sebesar 5,9\% dan sisanya dipengaruhi oleh variabel lain yang tidak diteliti dalam penelitian ini.

Jadi, Simpul Pertumbuhan Pelabuhan Paelangkuta Nusantara Raha berpengaruh positif dan signifikan terhadap Pengembangan Wilayah Kabupaten Muna.

\section{B. Saran}

1. "Kajian tentang konektivitas Pelabuhan Paelangkuta Nusantara Raha dengan pelabuhan lainnya di Kabupaten Muna berdasarkan distribusi barang dan jasa melalui kegiatan bongkar muat di pelabuhan paelangkuta nusantara raha".

2. "Kajian tentang dampak sosial dan ekonomi masyarakat Kabupaten Muna terhadap aktivitas utama di Pelabuhan Paelangkuta Nusantara Raha”.

3. "Kajian analisis pengaruh pengembangan Pelabuhan Paelangkuta Nusantara Raha terhadap wilayah hinterland Kabupaten Muna”.

\section{DAFTAR PUSTAKA}

Adisasmita, Raharjo. (2008). Pengembangan Wilayah Konsep dan Teori. Yokyakarta: Graha Ilmu.

Gantara, Wahyu Putra. Tri Achmadi. (2012). Model Pengembangan Wilayah untuk Pembangunan Pelabuhan (Studi Kasus: Pantai Selatan Jawa Timur). Jurnal Teknik Perkapalan. 1 (1). 
Henryk, Stepanus. (2013). Partisipasi Masyarakat dalam Pembangunan di Kelurahan Sungai Kledang Kecamatan Samarinda Seberang Kota Samarinda. E-Journal Ilmu Pemerintahan. 1 (2), 612-625.

Kastanya, Jori George Kherel Kastanya dkk. (2013). Perencanaan Pengembangan Pelabuhan Laut Serui di Kota Serui Papua. Jurnal Sipil Statistik. 1 (4), 233-239.

Mappangara, Andi Sitti Chairunnisa dkk. (2012). Kajian Jaringan Trayek Angkutan Laut Nasional untuk Muatan Petikemas dalam Menunjang Konektivitas Nasional, Seminal Teknik Sipil UMS 2012.

Purwanto, Erfan Agus dan Sulistyastuti, Dyah Ratih. (2011). Metode Penelitian Kuantitatif untuk Administrasi Publik dan Masalah-masalah Sosial. Yogyakarta: Gaya Media.

Setiono, Benny Agus. (2010). Analisis Faktor-Faktor yang Mempengaruhi Kinerja Pelabuhan. Jurnal Aplikasi Pelayaran dan Kepelabuhan. 1 (1). 